\title{
スギロータリー単板の密閉熱処理 ${ }^{+}$
}

$\begin{array}{lll}\text { 易 } & \text { 庠 華* 木 下 敍 幸** } \\ \text { 吉 延 匡 弘**関 惠 元** }\end{array}$

\section{Sugi Rotary Veneers Compressed by Hygro-Thermal Treatment with an Airtight Device Using Moisture in the Veneers}

\author{
by \\ Xianghua YI $^{*}$, Nobuyuki Kinoshita ${ }^{* *}$, Masahiro Yoshinobu ${ }^{* *}$ and Huiyuan GuAN ${ }^{* * *}$
}

\begin{abstract}
Sugi (Cryptomeria japonica) rotary veneers with thickness of $3.5 \mathrm{~mm}$ were compressed in the radial direction using the moisture content in the veneers enclosed in an airtight device set on a hot-press to improve its mechanical properties. The compressive deformation of the rotary veneers with moisture contents of $30 \%$ or more were approximately fixed by the compression at $200^{\circ} \mathrm{C}$ for 3 minutes or $180^{\circ} \mathrm{C}$ for 8 minutes : These conditions for permanent fixation of the rotary veneers were similar to those of Sugi sawed veneers. The resistance of surface to wear of the compressed rotary veneers was 2 times higher than those of the uncompressed veneers. The dynamic Young's modulus in the longitudinal direction of the rotary veneers increased with an increase in degree of compression. These improvements in the resistance of surface to wear and dynamic viscoelasticity in the longitudinal direction of the rotary veneers were similar to those of the sawed veneers and resulted from increased in density by compression. The dynamic Young's modulus in the tangential direction of the rotary veneers, however, scarcely increased by compression and was much less than that of the compressed sawed veneers. The specific dynamic Young's modulus in the longitudinal direction of the compressed rotary veneers also increased due to an increase in density by the compression, whereas that of the compressed sawed veneers did not vary. It was thought that the difference in the behavior of the specific dynamic Young's modulus between the rotary veneers and the sawed veneers was due to the lathe checks that existed only in the rotary veneers, that is, the compression disappeared from both of the voids of the cells and those caused by the lathe checks for the rotary veneers but disappeared only from the voids of the cells for the sawed veneers.
\end{abstract}

Key words : Sugi rotary veneer, Compression, Airtight device, Hygro-thermal treatment, Resistance of surface to wear, Recovery of set, Specific dynamic Young's modulus, Lathe checks, Sugi sawed veneer

\section{1 緒}

スギ材を繊維方向と直交する方向に加熱圧縮すると， 表面物性や力学性能の改善に対して効果があることが認 められている. ${ }^{1)}$ しかし，圧縮変形された材料の形状を固 定することは困難である，それを効果的に行う方法とし て, 高温高圧の水蒸気の雰囲気中で熱圧縮处理を行う方 法が提案されているが2, 3) これを寸法が大きな材料に適 用する場合には，材料中に存在している水蒸気を材外に 円滑に排出させることが困難であり，材料の割れや破損 などが発生する原因となる。材内水蒸気の圧力を低下さ せるために，熱圧縮処理後に加熱された装置を冷却する 方法が提案されているが,2)装置自体を加熱一冷却させる ことはエネルギー面や処理能率の面でも問題がある.

本研究では, 面寸法の大きな材料を短時間で効率的に 熱压縮处理し，学の処理材の変形回復量を小さくするた めに，材料としてべニヤレースで切削された厚さ $3.5 \mathrm{~mm}$
のスギロータリー単板を用い，これを密閉装置中で単板中 の水分を利用して水蒸気処理することによる効果を検討 した．このような密閉熱処理は既に多くの研究者によっ て試みられているが, (2) 4) 本研究はこれをロータリー単板 へ応用したものであり, スギ単板のような剛性が低い材 料を用いて, 構造用の合板や単板積層材 (LVL) を製造 する可能性を探ることを目的としたものである. 本論文 に打いては, 密閉熱処理による単板の変形固定性を評価 し, 耐摩耗性および動的粘弾性におよぼす処理効果につ いて, 特に動的粘弾性では挽き板材との比較を含めて検 討を行なった。

\section{$2 \cdot 1$ 供試単板}

\section{2 実 験 方 法}

供試材は, ベニヤレースで切削された気乾状態のスギ (Cryptomeria japonica) の $600 \mathrm{~mm}$ (繊維方向) $\times 480$ $\mathrm{mm}$ (接線方向 $) \times 3.5 \mathrm{~mm}$ (放射方向) の単板を用い

† 原稿受理 平成 15 年 7 月 2 日 Received July 2, 2003

* 正 会 岛根大学総合理工学部材料プロセス工学科 †690-8504 松江市西川津町, Faculty of Sci. and Eng., Shimane Univ., Nishikawatsu-cho, Matsue, 690-8504

** 島根大学総合理工学部材料プロセス工学科＝690-8504 松江市西川津町, Faculty of Sci. and Eng., Shimane Univ., Nishikawatsu-cho, Matsue, 690-8504

*** 南京林業大学木材工業学院 南京 210037, College of Wood Sci. and Tech. Nanjing Forestry Univ., Nanjing, P. R China, 210037 
た. スギ挽き板材の寸法は $250 \mathrm{~mm}$ (繊維方向 $) \times 25 \mathrm{~mm}$ (接線方向 $) \times 3.5 \mathrm{~mm}$ （放射方向）である。気乾状態の 単板試料を室温の水中に浸せきし，含水率がおよそ $15 \%$, 30\%，60\%，100\%，150\%になるように調整した。 ここで， 含水率が $15 \%$ の単板については, 室温の水中に 30 分程 度浸せきした後, 室内に 1 ケ月以上放置した。 また，他 の含水率条件については，単板の全乾重量と目標含水率 から推定される単板重量になるように水中に浸せきした 後, ビニルフィルムで包み, 室内に放置した。

\section{$\mathbf{2} \cdot \mathbf{2}$ 実験装置}

本研究に用いた装置は，単板をセットする耐圧密閉ス ペースと排気弁およびシリコンゴムからなる，本装置は

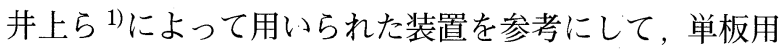
に新たに製造したものである。密閉スペースの寸法は $700 \mathrm{~mm}$ (幅) $\times 500 \mathrm{~mm}$ (奥行き) $\times 15 \mathrm{~mm}$ （深さ）であ る. 装置本体の縁に幅 $5 \mathrm{~mm}$, 深さ $5 \mathrm{~mm}$ の溝が加工され ている。その溝の中に密閉用シリコンゴムを取り付け， 熱圧縮処理中にスペース内に充満する水蒸気が外部に漏 出するのを防止した. 圧縮量の設定は, 厚さの異なるス ペーサー（695mm × 495mm）を用いて行った．密閉加 熱圧縮処理する際の装置内部の自由空間は, 装置空間の 約 $3.5 \%$ であった.

\section{$2 \cdot 3$ 密閉熱処理}

密閉熱処理の実験装置をホットプレスの下部熱板の上 に設置し，これを所定の温度まで加熱した。その後，ス ギ単板を実験装置内にセットして密閉熱処理を行った. 所定の処理時間が経過した後，単板を実験装置から取り 出す前に, 排気弁（排気口径 $3 \mathrm{~mm}$ ）を全開にし，密閉 スペース内の水蒸気を排出させ，冷却過程を経ることな く，処理を完了した。このときの排気時間は，単板の含 水率に応じて約 $2 \sim 5$ 分とした. なお，スギ単板が実験 装置に固着するのを防止するために, 単板上下面に厚さ $0.1 \mathrm{~mm}$ のテフロンフィルムを敷いた。 下側のテフロンフ ィルムには, 単板内からの水蒸気の排出を円滑に行い, 単板表面の割れを防止するために，直径 $1 \mathrm{~mm}$ のを $10 \mathrm{~mm}$ 間隔で開けた. さらに，このテフロンフィルムの 下に，厚さ $0.12 \mathrm{~mm}$ ，目開き $0.3 \mathrm{~mm}$ の金網を敷いた．金 網による単板表面の凹凸痕が処理単板を用いた合板あ るいはLVLの製造において問題とはならないことは，処 理単板より製造した LVLの接着性能評価の結果から確認 した.10)

密閉熱処理条件は熱板温度 $160,180,200^{\circ} \mathrm{C}$, 時間 1 16 分間，圧縮率 $50 \%$ とした。比較のために，スギの挽き 板材について同様の処理を施した。

\section{$2 \cdot 4$ 単板厚さの回復度}

処理ロータリー単板の厚さ変形の固定状態を評価する ため, 処理された単板を全乾状態まで乾燥した後, 15 分 間〜 48 時間の範囲内で所定時間煮沸した．所定時間後 に取り出したそれぞれの 試験体を $105^{\circ} \mathrm{C} て ゙ 24$ 時間以上 乾燥し, 処理前後の厚さから式 (1)により単板厚さの回 復度 S (\%)を求めた. ${ }^{5)}$ 測定後, 試験体は再び煮沸処理に供 した.これを繰り返し，回復度の経時変化を算出した。

$$
\mathrm{S}=\frac{\mathrm{h}_{2}-\mathrm{h}_{1}}{\mathrm{~h}_{0}-\mathrm{h}_{1}} \times 100
$$

ここで, $\mathrm{h}_{0}(\mathrm{~mm})$ は密閉熱処理前の単板の厚さ, $\mathrm{h}_{1}$ $(\mathrm{mm})$ は密閉熱処理後の単板の厚さ, $\mathrm{h}_{2}(\mathrm{~mm})$ は者沸処 理後の単板の厚さであり，全て全乾状態の厚さである。 全乾状態における密閉熱処理前の単板の厚さは, 密閉熱 処理のための単板試験体に隣接して $20 \mathrm{~mm} \times 20 \mathrm{~mm}$ の試 験体を採り, $105^{\circ} \mathrm{C} て ゙ 24$ 時間以上乾燥して測定した。

\section{$2 \cdot 5$ 単板の動的ヤング率}

密閉熱処理ロータリー単板および未処理単板から $250 \mathrm{~mm}$ (繊維方向 $) \times 25 \mathrm{~mm}$ （接線方向）の試験体を作 製し, 試験体を恒温恒湿室 $\left(20^{\circ} \mathrm{C}, 60 \% \mathrm{RH}\right)$ 内に 1 週間 放置した後，繊維方向に対して動的ヤング率を測定した. ヤング率の測定は, 片持ちはり（一端固定他端自由）の たわみ振動法で行った. 自由振動部分の長さは $200 \mathrm{~mm}$ である.ヤング率 $\mathrm{E}(\mathrm{Pa})$ はたわみ振動の 1 次モードの 固有振動数によって求めた.6)

$$
\mathrm{E}=\frac{48 \pi^{2} \mathrm{~F}^{2} 1^{4}}{\lambda_{1}^{4} \mathrm{~h}^{2}} \rho
$$

ここで, F ( Hz) はたわみ振動の 1 次モードの固有振動 数, $\rho\left(\mathrm{g} / \mathrm{cm}^{3}\right)$ は試験体の密度, $\mathrm{h}(\mathrm{mm})$ は試験体の厚 さ, $1(\mathrm{~mm})$ は試験体の振動部分の長さ， $\lambda_{1}$ はたわみ振 動の 1 次モードの固有值 $\left(\lambda_{1}=1.875\right)$ である.

スギ挽き板材についても, 同じサイズの試験片を用い て測定を行い, ·単板との比較を行なった.

また，ロータリー単板の接線方向に対してのヤング率 は, 一般的に極めて低いことが知られているが, 本研究 におけるような密閉熱処理によっても，僅かに改善され るのみであった. そのため, 繊維方向に対しての測定試 験片の作成とは異なり, 接線方向に対してのヤング率の 測定試験片の正確な作成は割れや欠けの発生により困難 であった．以上のことから，本論文では接線方向に対す る試験は行なわず, 繊維方向に対する動的ヤング率のみ を測定した。

\section{$2 \cdot 6$ 単板表面の摩耗性}

密閉熱処理ロータリー単板および未処理単板を $110 \mathrm{~mm}$ (繊維方向 $) \times 110 \mathrm{~mm}$ （接線方向）に切断し, 密度を測 定した後，市販のユリア樹脂接着剤を用い， $5 \mathrm{~mm}$ (厚さ) $\times 110 \mathrm{~mm} \times 110 \mathrm{~mm}$ の合板に貼って摩耗性測定用の試験 体とした。このときの接着条件は, 常温下, 圧締圧力 $0.5 \mathrm{kgf} / \mathrm{cm}^{2}$ とし, 単板が再圧縮されないように留意した。 測定は回転型摩耗装置を用いて行った.7)試験条件は, 研 摩紙粒度 \#240, 研摩紙幅 $12 \mathrm{~mm}$, 研摩ローラの直径 $55 \mathrm{~mm}$, 研摩ローラの荷重 $750 \mathrm{~g}$ とした。摩耗量 $\mathrm{d}(\mathrm{mm})$ は式 (3)によって求めた. ${ }^{11)}$

$$
\mathrm{d}=\frac{10\left(\mathrm{w}_{0}-\mathrm{w}_{1}\right)}{\rho_{A}}
$$

ここで, $\mathrm{W}_{0}(\mathrm{~g})$ は摩耗前の試験体の重量, $\mathrm{W}_{1}(\mathrm{~g})$ は摩 耗後の試験体の重量, $\mathrm{A}\left(\mathrm{cm}^{2}\right)$ は摩耗を受ける面積, $\rho\left(\mathrm{g} / \mathrm{cm}^{3}\right)$ は試験体の密度である.

\section{$2 \cdot 7$ 単板裏割れ面の断面観察}

単板裏割れの断面観察は Nikon 社製 SMZ-10A-2 型電 子顕微鏡を使用した。 


\section{3 結 果 と 考 察 \\ $3 \cdot 1$ 密閉熱処理前後の単板の含水率}

ロータリー単板の含水率が高い場合には，処理中に割 れやパンクなどの発生が懸念された。そこで, 単板の含 水率を $15 \%$ ～ $150 \%$ の範囲で変化させ， $180^{\circ} \mathrm{C}, 10$ 分間 の密閉熱処理を行ったところ, 割れやパンクなどは発生 しなかった. これは, 単板の厚さが薄く, 裏割れがあり, 単板からの水蒸気排出を円滑に行う対策を施したことに よると推察された.

\section{$3 \cdot 2$ 密閉熱処理単板の厚さの回復度に及ぼす単板の 含水率の影響}

$3 \cdot 1$ 節と同様の条件で密閉熱処理したロータリー単板 についての，1 時間煮沸後の単板厚さの回復度に及ぼす 単板の含水率の影響を Fig. 1 に示す. 単板厚さの回復度 は，単板の含水率が $15 \%$ の場合は $43 \%$ であったが，含水 率が $30 \%$ 以上の場合はいずれも $5 \%$ 以下となり，含水率 による明確な差異は認められなかった。この傾向は，含 水率 $15 \%$ で $43 \%$ の回復度はこれまでの報告に比べて幾分 高いが，挽き板材の場合と類似した結果である.9)

提案されている熱圧縮処理に伴う変形固定化機構 ${ }^{3), 4)}$ に従うならば，単板の処理における水分の作用は以下の ように説明される. 密閉熱処理直後の単板の含水率は約 $1.2 \%$ であったことから, 単板内に含まれていた水分の一 部は加熱されることによって気化し，生じた水蒸気の一 部が単板内に残存し, また一部は単板外の密閉装置内に 充満するが，残りは液体状態で存在する，圧縮後，水蒸 気を排出させ，単板内部の圧力を解放し，急激に気化招 よび乾燥が進行するものと考えられる。したがって，単 板の水分により装置内の蒸気圧は上昇するが，単板の含 水率が低い場合には，この蒸気圧が低く，変形固定の効 果が小さくなったと思われる.

以上の結果を踏まえて，以後の実験は含水率を $30 \%$ $60 \%$ に調整した単板について行った。

\section{$3 \cdot 3$ 密閉熱処理単板の厚さの回復度}

$160^{\circ} \mathrm{C}, 180^{\circ} \mathrm{C}, 200^{\circ} \mathrm{C}$ で密閉熱処理したスギロータリー 単板を 15 分間〜 48 時間の範囲で煮沸した時の単板厚さ

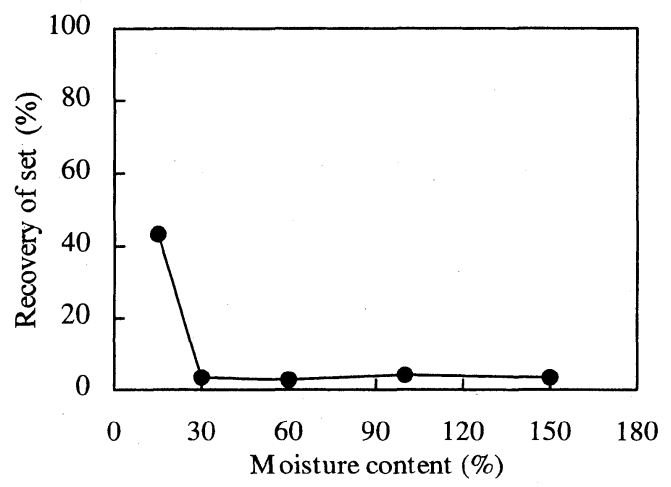

Fig. 1. Effect of the initial moisture content of Sugi rotary veneer on set recovery in thickness of the compressed Sugi rotary veneer.

Note : Sugi rotary veneer were compressed at $180^{\circ} \mathrm{C}$ for $10 \mathrm{~min}$.

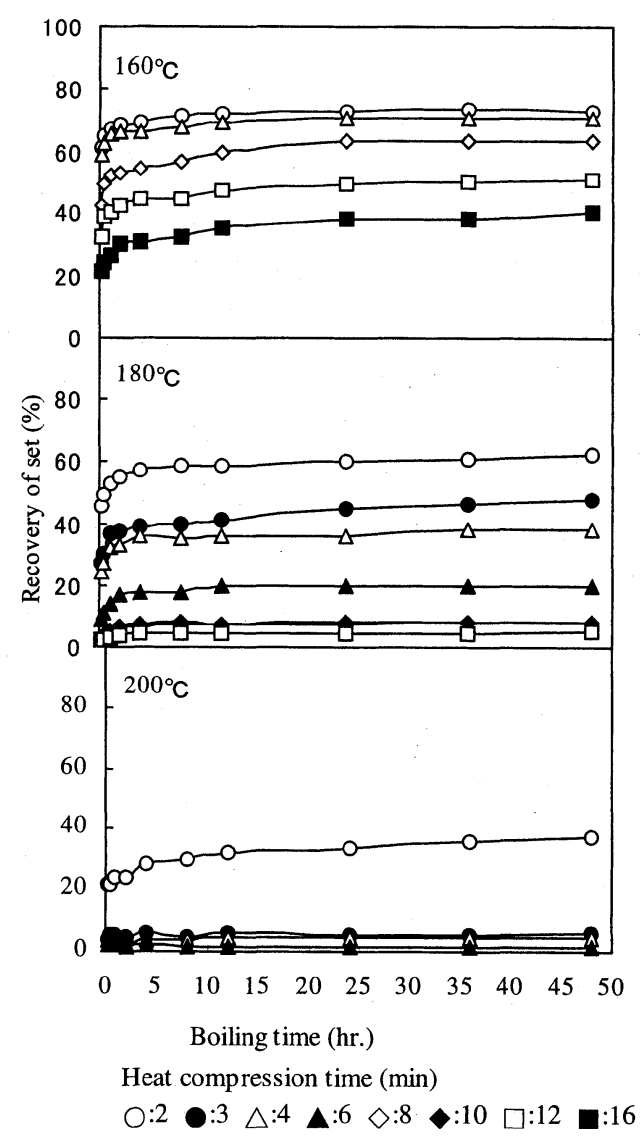

Fig. 2. Effect of boiling time on set recovery in thickness of the compressed Sugi rotary veneer. Note : Sugi rotary veneer were compressed at $180^{\circ} \mathrm{C}$ for $10 \mathrm{~min}$.

の回復度の測定結果を Fig. 2 に示す。プロットは式 (1) に示したように所定時間煮沸したのち乾燥後の厚さを用 いて, 回復度を算出した. すなわち, 乾燥状態の回復度 である，者沸時間が長くなるほど単板厚さの回復度は大 きくなったが, 処理温度が $180^{\circ} \mathrm{C}$ で処理時間を 10 分間以 上に設定した場合，あるいは処理温度が $200^{\circ} \mathrm{Cで}$ 処理時 間を 3 分間以上に設定した場合には，単板厚さの回復度 は煮沸時間に依らずほぼ一定であり，単板厚さの回復度 はいずれも5\%以下であった。しかし，処理温度が $160^{\circ} \mathrm{C}$ の場合には，处理時間を 16 分間に設定しても，単板厚 さの回復度は $25 \%$ 以上と大きく, 単板の圧縮変形の固定 が不十分であった。

密閉熱処理温度および時間を变化させて処理した単板 について処理時間依存性を Fig. 3 に示す。困は 1 時間煮 沸後の単板厚さの回復度に関するものである.いずれの 処理温度の場合に扔いても, 単板厚さの回復度は处理時 間が長くなるにつれて減少した。処理時間が同じ場合に は, 温度が高くなるほど回復度は小さくなった。

単板における熱処理条件と回復度との関係は，上記の ようにおおむね板材において報告された傾向と類似の傾 向を示し, その変形固定化機構が挽き板材と同じである と推察された。

\section{$3 \cdot 4$ 密閉熱処理単板表面の摩耗性}

$180^{\circ} \mathrm{C}, 10$ 分間で密閉熱処理を行ったロータリー単板 


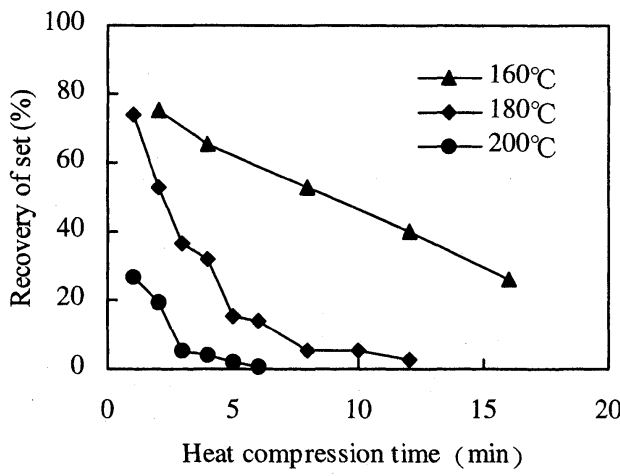

Fig. 3. Effect of heat compression time on set recovery in thickness of the compressed Sugi rotary veneer. Note : Sugi rotary veneers were compressed at $180^{\circ} \mathrm{C}$ for $10 \mathrm{~min}$.

および未処理単板について, 単板表面の摩耗量を測定し た結果を Fig. 4 に示す。単板表面の摩耗量は摩耗距離が 長くなるにつれて増加し, 摩耗距離 $520 \mathrm{~m} に お け る$ 处理 単板打よび未処理単板の摩耗量はそれぞれ $1.02 \mathrm{~mm}$ 打よ び $0.50 \mathrm{~mm}$ であった。密閉熱処理を行うことによって， 単板表面の摩耗量は $1 / 4 \sim 1 / 2$ 程度に減少し, 处理単板 表面の耐摩耗性は著しく向上した。これは, 密度増大に よるものである.

\section{$3 \cdot 5$ 密閉熱処理単板の繊維方向に対する動的ヤング率}

これまで述べてきたように，ロータリー単板への密閉 熱処理は，挽き板材への処理と概禎似した特性を与え， したがってその変形固定化機構も同じであると推察さ れた.

Fig. 5 に, $180^{\circ} \mathrm{C}, 10$ 分間で密閉熱処理を行ったロー タリー単板および未处理単板について, 動的ヤング率を 密度に対してプロットしたものを，挽き板材の結果ととも に示した。 未処理ロータリー単板の動的ヤング率は 1.51 6.11GPaであったが，密閉熱処理を行うことによって， ロータリー単板の動的ヤング率は $4.87 \sim 13.29 \mathrm{GPa} へ と$ 増大した。 未処理ロータリー単板および処理ロータリー単 板の密度は，それぞれ $0.25 \sim 0.37 \mathrm{~g} / \mathrm{cm}^{3}$ およ゙ 0.54

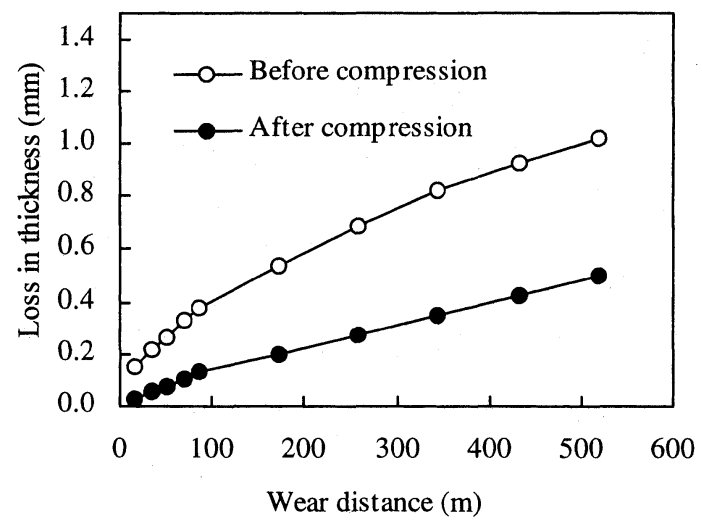

Fig. 4. Relationship between loss in thickness and wear distance of the Sugi rotary veneer.

Note : Sugi rotary veneer were compressed at $180^{\circ} \mathrm{C}$ for $10 \mathrm{~min}$

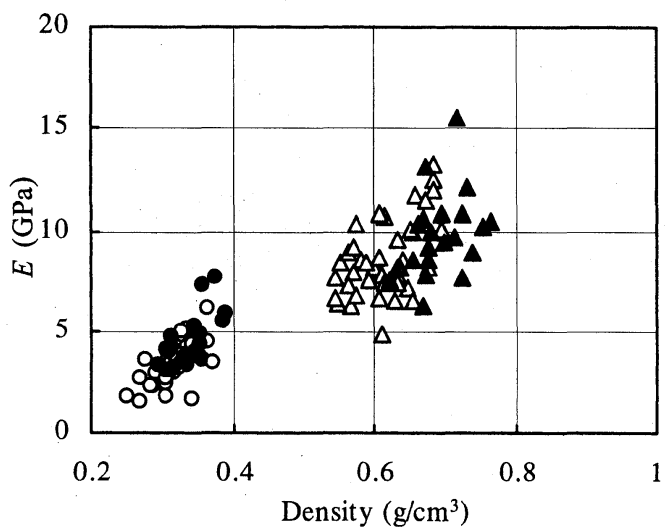

Fig. 5. Relationship between the dynamic Young's modulus and density of the Sugi veneers.

Note : Sugi veneers were compressed at $180^{\circ} \mathrm{C}$ for $10 \mathrm{~min}$.

Symbols : $\bigcirc$, Sugi rotary veneer before compression ;

- Sugi sawed veneer before compression ;

$\triangle$, Sugi rotary veneer after compression ;

$\boldsymbol{\Delta}$, Sugi sawed veneer after compression.

0.70 $/ \mathrm{cm}^{3}$ であった。図から明らかなように，ロータリー 単板のプロットは挽き板材の結果と比較しては幾分低密 度側に位置した。これは，裏割れによるロータリー単板 密度低下によるものと考元られる。動的ヤング率と密 度との関係は，ロータリ一単板と挽き板材ともに，処理 の有無に関わらず，密度の増大に伴い増大する傾向を示 した.

Fig. 6 に比ヤング率と密度との関係を示す．両者の相 関はほぼないとみなせることから，密閉熱处理前後の比 ヤング率の平均値について，その差の検定 (T検定) と

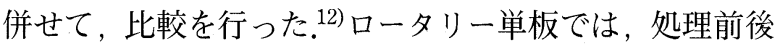
の平均值の差は有意水準 0.01 で有意差ありと検定され， 密閉熱処理によって比ヤング率の平均值は拉よそ 1.3 倍 に増大した。これに対して，挽き板材では，処理前後の 平均値は有意差なしと検定され，密閉熱処理によって比 ヤング率はほとんど変化しなかった。

婏き板材を用いた熱処理に抢いては，圧縮率が増加す るにつれてヤング率は高くなるが，比ヤング率はほとん ど変化しないことが知られている. ${ }^{1)}$ Fig. 6 に示したよう に，本実験に打いてロータリー単板の比較として実施し た挽き板材の結果もまた，同様であった。ロータリー単 板ではヤング率が上昇したものの，乥れは処理前に比べて であり，処理後の絶対值は板材のそれとほぼ同じであった ことを考慮すると，ロータリー単板の处理前の比ヤング 率が挽き板材に比べて低いことが，両者の熱处理による 変化の違いとして発現したと言える。

上記結果は，裏割れの関与と関連付けて考えることが できるので, ヤング率への裏割れの寄与を以下において 考察する。

一般に木材は空隙と実質との複合材料であるから，大 鉒ら ${ }^{8)}$ が示したようにそのヤング率 $\mathrm{E}_{\mathrm{W}}$ は式 (4)で与えら れる。 


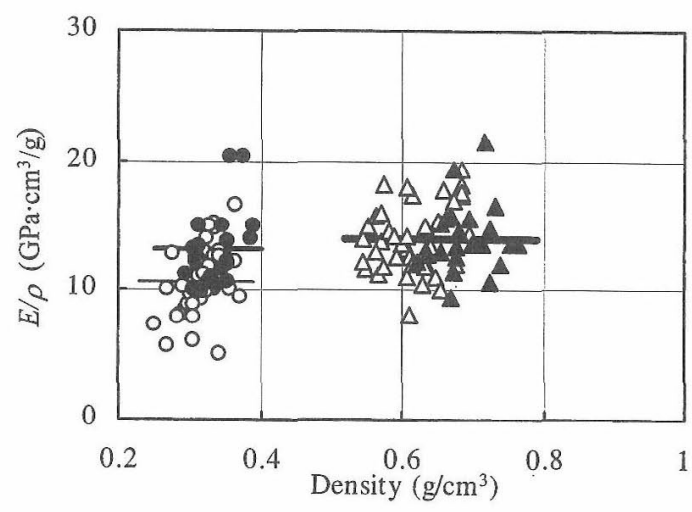

Fig. 6. Relationship between the specific dynamic Young's modulus $(E / \rho)$ and density of the Sugi veneers.

Note : Sugi veneers were compressed at $180^{\circ} \mathrm{C}$ for $10 \mathrm{~min}$.

Symbols: $\bigcirc$, Sugi rotary veneer before compression;

, Sugi sawed veneer before compression ;

$\triangle$, Sugi rotary veneer after compression ;

$\Delta$, Sugi sawed veneer after compression;

-, The average of the specific dynamic Young's modulus of Sugi rotary veneer before compression.

-, The average of the specific dynamic Young's modulus of Sugi sawed veneer before compression ;

-, The average of the specific dynamic Young's modulus of Sugi rotary veneer and Sugi sawed veneer after compression.

$$
\mathrm{E}_{\mathrm{W}}=\theta^{\mathrm{n}} \mathrm{E}_{\mathrm{s}}
$$

ここで，０は実質率，nは形状に関わる定数，ES は実質 のヤング率である。本実験でのヤング率は曲げであるか ら，空隙と実質は力線方向に対して並列とみなせる。元 こで, 粗い近似であるが, $\mathrm{n}=1$ と近似する。さらに, 木材実質の密度を $\rho_{0}$, 木材全体の密度を $\rho$ とす机ば， $\theta$ $=\left(1 / \rho_{0}\right) /(1 / \rho)$ である。したがって，

$$
\mathrm{E}_{\mathrm{w}}=\left(\frac{\rho}{\rho_{0}}\right) \mathrm{E}_{\mathrm{s}}
$$

あるいは，

$$
\frac{\mathrm{E}_{\mathrm{W}}}{\rho}=\frac{\mathrm{E}_{\mathrm{S}}}{\rho_{0}}
$$

式 (5) はヤング率が密度に比例することを示すもので西 り，式 (6) は穾質のヤング率と密度に対する熱処理によ る寄与が同じであれば，E/ $/$ が一定となることを示す。 先に述べたように挽き板材の圧密化において比ヤング率 はほとんど変化しないことが知られているが，このこと は熱処理による寄与がヤング率と密度に対して線形であ ることを示唆する。

ロータリー単板の力学的特性を考える場合, 挽き板材 にはない因子がある。乥れは裹割れである。式 (5)，(6) はこの裹割れの寄与を考慮していない. Fig. 7 は測定し た試騟片断面の実態顕微鏡写真である。密閉熱処理前の ロータリー単板では裏割れに伴う空陌が顕著に認められ た。一方, 処理後の単板では, 裏割れに伴う空陌はほと んど認められなかった。これらの結果は, 処理によって
Before compression

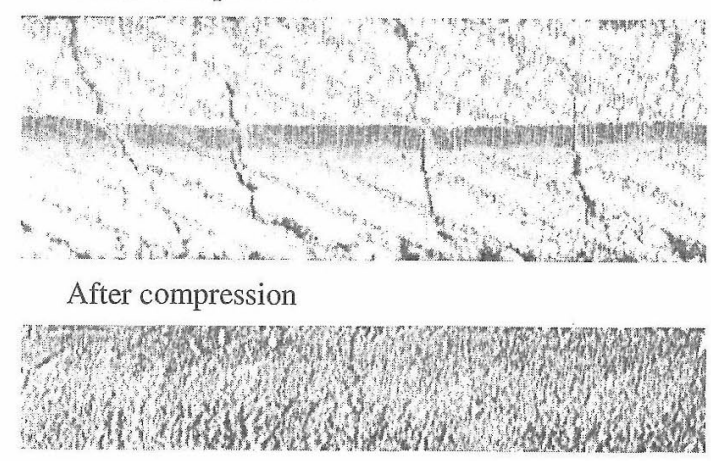

Fig. 7. Lathe checks of the side surface of Sugi rotery veneer before and after compression.

裏割れによる空隙がほとんど消失したものと考えてよい ことを示している。

いま, ロータリー単板のヤング率を $\mathrm{E} と し$ 裏割れの体積 分率を入とすれば，裏割れが材の繊維方向に生じること を考えると， EW を得た同じ手順で E を式 (7)として得る.

$$
\mathrm{E}=(1-\lambda) \mathrm{E}_{\mathrm{w}}=(1-\lambda)\left(\frac{\rho}{\rho_{0}}\right) \mathrm{E}_{\mathrm{s}}
$$

あるいは，

$$
\frac{\mathrm{E}}{\rho}=(1-\lambda)\left(\frac{1}{\rho_{0}}\right) \mathrm{E}_{\mathrm{s}}
$$

を得る。

密閉熱処理は処理条件が厳しくなるほど密度が増大す るが，そのことは同時に裹割れに伴う空陌率を減少する。 熱処理条件が谖しくなるほじ裏割れ率が減少するとき，

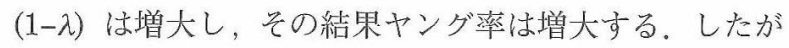

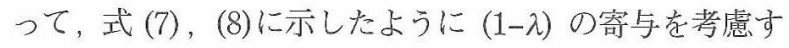
れば，ロータリー単板と挽き板材との処理前後の比ヤン グ率の違いは説明可能である。

压密化は挽き板材に対しては空隙を潰すという作用を 及ぼすが，ロータリ一単板においてはそれに加えて裏割 れに伴う究隙を減少する。このことは，比ヤング率に関 しては，処理によってロータリー単板と婏き板材との差 はなくなることを意味する。その結果, 比ヤング率と密 度との関係は, ロータリー単板においては処理前後で変 化を生じる。

以上の議論から，䋊維方向に対する性質に関しては， ロータリー単板を用いても，挽き板材と同程度の繊維方 向に対するヤング率を有する熱压縮処理材が得られるこ とがわかる。このことは，ロータリ一単板の歩留まりが 高いことを考慮するならば，資源利用の観点から，ロー タリー単板を用いた熱圧縮処理が有効であることを示し ている。

\section{4 結 論}

低密度，低剛性のスギ材を利用して構造用合板あるい は構造用単板積層材の製造を目的として，その構成エレ メントであるベニヤレースで切削された厚さ $3.5 \mathrm{~mm}$ のス ギロータリー単板の密閉㪇処理を試み, 只の物性を挽き 板材の場合と比較した。結果は, 以下の通りである。 
（1）密閉装置中で単板中の水分を利用した水熱処理 で圧縮することにより，ベニヤレースで切削された直後 の高含水率状態のスギロータリー単板の厚さの固定が可 能であった。単板の厚さ方向に打ける変形を固定できる

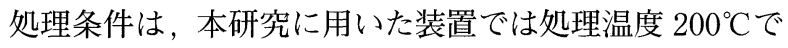

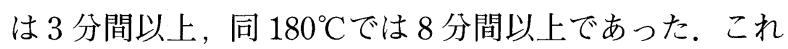
は異なる装置で得られた挽き板材の結果とほほ同じ傾向 を示すものであった，処理を行うことにより，密度増大 によりロータリー単板においても挽き板材同様に表面耐 摩耗性が改善された。

(2) 繊維方向に対する動的ヤング率と密度との関係 は，ロータリー単板と挽き板材ともに処理の有無に関わ らす密度の増大に伴い増大する傾向を示した，比ヤング 率と密度との関係において，ロータリー単板では挽き板 材とは異なり処理依存性が認められ, 比ヤング率が処理 によって増加した．挽き板材とロータリー単板のこの違 いは，ロータリ一単板に生じる裏割れの寄与によるもの であった。一方，処理後の単板の接線方向に対する動的 ヤング率は挽き板材と比較して極めて低く，処理による 改善効果は僅かであった。

以上のように，本研究で試みたロータリー単板を用い た密閉熱処理は，(a)ロータリー単板の歩留まり，すなわ ち資源化率が高いこと，(b) 大きな面積の材料を比較的 短時間に効率良く処理可能であること，および (c) 結果 として引き起こされる裏割れに伴う空陌の減少により， 表面の耐摩耗性や繊維方向に対する粘弾性といった力学
性能が向上することから，スギ材のような一般的に低質 とされる木材資源の有効な利用法の一つであると思われ る。今後は，密閉熱処理によって剛性を改善したスギ単 板と用いて各種の LVLを製造し，その構造用材としての 可能性について，詳細な検討を進める計画である.

\section{参 考 文 献}

1) 井上雅文, APAST, 17, 5 (1995).

2) 棚橋光彦, APAST, 7, 10 (1993).

3 ) M. Inoue., M. Norimoto, M. Tanahashi and R. M. Rowell, Wood and Fiber Sci., 25, 224 (1993).

4) 井上雅文, 門川倫子, 西尾治郎, 則元 京, 木材研究 資料，29，54（1993）.

5 ）宇高英二, 古野 毅, 木材学会誌, 44, 218 (1998).

6 ）佐藤秀紀, 岡部佐規一, 岩田佳雄, “機械振動学”, p.170 （1995）工業調査会.

7 ）柳下 正, “特殊合板”, p.302（1967）森北出版(株).

8 ）大釡敏正, 山田 正, 材料, 20, 1194 (1971).

9) 井上雅文, 門川倫子, 西尾治郎, 則元 京, 第 43 回日本 木材学会大会研究発表要旨集, 614（1993）.

10）易庠華，木下敍幸，吉延匡弘，関 惠元，木材工業， 58, 588 (2003).

11）日本規格協会, “JIS Z 2141 木材の摩耗試験方法”, p.341 (2002).

12）大滝 厚, 鈴木和幸, 長澤伸也, “パソコン BASIC 統計解 析”, p.119（1991）東海大学出版会. 